\title{
Status Analysis and Research on Teaching System of Hand-drawing Course
}

\author{
Yu Gui \\ College of Horticulture and Gardening \\ Tianjin Agricultural University \\ Tianjin, China \\ 36361950@qq.com
}

\author{
Jinghui Yang* \\ College of Horticulture and Gardening \\ Tianjin Agricultural University \\ Tianjin, China \\ 1374067056@qq.com
}

\begin{abstract}
Hand-drawing course plays a link role in the teaching of the modern art design. It is between the basic course and the professional course, which has a great influence on the students' further education and employment. Through the questionnaire survey on the students of the art design majors of Tianjin Agricultural University, Nanjing Forestry University and South China Normal University, this paper analyzed the teaching status from four aspects in the hand-drawing course, including teaching purposes, teaching content, teaching methods and results evaluation. It is found that there are three problems in the teaching of hand-drawing course, that are single teaching content, lack of reformation and innovation in teaching methods and imperfect evaluation system of teaching results. This paper proposes that the teaching goal of the hand-drawing course should be changed from pursuing the effect picture to mastering the ability of sketching and quick-drawing. The teaching content should be diversified, and teaching methods of the hand-drawing course should be reformed and innovated. It is necessary that the emphasis of the teaching system converts from a single performance ability to practical design ability, so that the handdrawing course can improve students' design creativity.
\end{abstract}

Keywords-Hand-drawing course; teaching objectives; teaching methods; teaching system

\section{INTRODUCTION}

Before the 1980s, China's hand-drawing course was influenced by craft art. Art design education was mainly based on drawing, including the hand-drawing effect picture course in environmental design major. The basic course, professional course and practical course in the professional teaching system of this major focused on the development of students' drawing ability and performance ability in decoration and beautification. After the 1980s, Chinese art design education began to develop from decoration and beautification to practicality. In 1998, the Ministry of Education of China promulgated the major catalog of higher education. In the new catalogue, "art design" replaced "craft art", and Chinese design education entered a new beginning. However, Chinese modern art design education only borrows some of Bauhaus's curriculum and teaching content in the form and does not blend the essence of Bauhaus into art design education. Modern art design and subject planning are still based on drawing. Basic course and professional course emphasize drawing, and "painting" is the main form of expression design,

Tianjin Agricultural University Education and Teaching Research and Reform Project (2018A05) which makes art design unable to get rid of the influence of the art[1].

In the hand-drawing course, compared with the art drawing, hand-drawing effect pictures pay more attention to practicality and more respect the objective design and customer requirements to ensure the feasibility of the actual operation. The art drawing pays more attention to the artistic thinking of the expressers. In the environmental design major, handdrawing is mostly used in the initial stage of the program to express the designer's scheme concept and it adopts the quick expression method. Compared with the computer and the ruler drawing, the hand-drawing effect picture emphasizes the freehand drawing. With the development of technology, computer graphics are widely used. Students use computer software copying and simulating design for a long time, that will affect students' design ability. In the process of freehand drawing, students can improve aesthetics and design ability. There are some positive effects, such as improving students' innovative thinking and designing comprehensive literacy. Thinking produces design, and design is driven and deepened by performance. Hand-drawing expresses design concepts in a way that quickly records designer ideas and innovative thinking, so it promotes interaction between designers and customers. In the environmental art design. The hand- drawing course has a great impact on students' careers and employment. It is between the basic course and the professional course, which plays a link role in course setting [2].

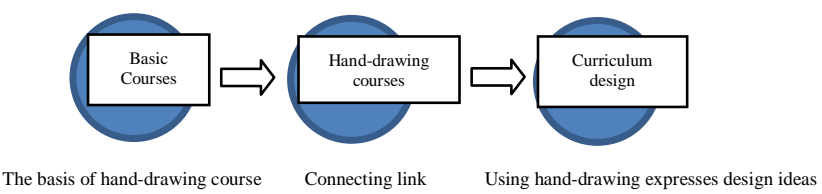

Fig. 1. The role of hand-drawing course in design major

\section{STATUS INVESTIGATION OF THE HAND- DRAWING COURSE}

The rapid performance is closely related to the designer's personal ability and professional accomplishment. It is the performance of the thinking process. The expression skill in effect picture can be improved in short-term training, but the design thinking ability is a long-term accumulation process, and it cannot be done overnight in a few dozen class hours in the hand-drawing course. It is difficult to improve the design 
level but achievement of excellent effect picture is relatively easy.

Various hand-drawing training institutions in the society are popular and the emergence institutions indicate the lack of teaching system. The daily hand-drawing teaching in universities is only teaching techniques rather than design, and students' rapid performance and sketch skills cannot be improved. With the high popularity of postgraduate education, the hand-drawing course pays more attention to the cultivation of hand-drawn sketching ability and rapid expression ability. Hand-drawing features with the quick record and convenient expression, and it is essential in program display, customer communication, drawing modification and construction. However, the hand-drawing effect picture is mostly used in the presentation stage of the final result. It is required the realistic effect, and most of its features are replaced by computers [3].

In this paper, self-made questionnaires were used to investigate the students who opened hand-drawing courses in Tongji University, Tianjin Agricultural University, Nanjing Forestry University, and South China Normal University. A total of 630 people conducted questionnaire surveys. There were 610 valid questionnaires and 20 invalid questionnaires. The following is a list of hand-drawing courses in four universities in China. As shown in TABLE I.

TABLE I. RESEARCH ON HAND-DRAWING COURSES RELATED TO DESIGN MAJORS IN VARIOUS UNIVERSITIES

\begin{tabular}{|c|c|c|c|c|}
\hline University & Major & Course & Start time & $\begin{array}{l}\text { Notes: hand-drawing related } \\
\text { courses or follow-up courses }\end{array}$ \\
\hline $\begin{array}{l}\text { Tongji } \\
\text { University }\end{array}$ & $\begin{array}{l}\text { Architecture major } \\
\text { (indoor design } \\
\text { direction) }\end{array}$ & Indoor Environmental Performance & $\begin{array}{l}\text { last semester of junior year ( } 34 \\
\text { class hours in total) }\end{array}$ & $\begin{array}{l}\text { Practice arrangement: Interior } \\
\text { Design Week ( next semester of } \\
\text { junior year, } 1 \text { week) } \\
\text { Building fast design ( next } \\
\text { semester of senior year, } 3 \text { weeks) }\end{array}$ \\
\hline $\begin{array}{l}\text { South China } \\
\text { Normal } \\
\text { University }\end{array}$ & $\begin{array}{c}\text { Art design major } \\
\text { (environmental design } \\
\text { direction) }\end{array}$ & $\begin{array}{l}\text { Design Performance Technique } 1 \\
\text { (Architectural Performance } \\
\text { Technique) } \\
\text { Design Performance Technique } 2 \\
\text { (Indoor Performance Technique) }\end{array}$ & $\begin{array}{l}\text { next semester of sophomore year } \\
\text { ( } 45 \text { class hours in total) } \\
\text { last semester of junior year ( } 45 \\
\text { class hours in total) }\end{array}$ & $\begin{array}{l}\text { Fast design course in a } \\
\text { professional limited course (60 } \\
\text { class hours in total) }\end{array}$ \\
\hline $\begin{array}{l}\text { Tianjin } \\
\text { Agricultural } \\
\text { University }\end{array}$ & $\begin{array}{l}\text { Art design major } \\
\text { (environmental design } \\
\text { direction) }\end{array}$ & $\begin{array}{c}\text { Performance Technique } 1 \text { (pen and } \\
\text { ink) } \\
\text { Performance Technique } 2 \text { (hand- } \\
\text { drawing outdoor effect picture) } \\
\text { Performance technique } 3 \text { ( hand- } \\
\text { drawing indoor effect picture ) }\end{array}$ & $\begin{array}{c}\text { next semester of the fresh year (48 } \\
\text { class hours in total) } \\
\text { next semester of sophomore year } \\
\text { ( } 36 \text { class hours in total) } \\
\text { last semester of junior year (36 } \\
\text { class hours in total) } \\
\end{array}$ & $\begin{array}{l}\text { Practice arrangement : sketch } \\
\text { skill practice ( next semester of } \\
\text { sophomore year, } 1 \text { week) }\end{array}$ \\
\hline $\begin{array}{l}\text { Nanjing Forestry } \\
\text { University }\end{array}$ & $\begin{array}{l}\text { Landscape architecture } \\
\text { major }\end{array}$ & $\begin{array}{l}\text { Non-independent course, related to } \\
\text { the hand-drawing course in the initial } \\
\text { course of landscape design }\end{array}$ & $\begin{array}{l}\text { next semester of a fresh year and } \\
\text { last semester of sophomore year } \\
\text { (about one-third of } 64 \text { class hours) }\end{array}$ & $\begin{array}{l}\text { Arranging sketching study in the } \\
\text { basic art course }\end{array}$ \\
\hline
\end{tabular}

It can be seen from TABLE I that architecture major of Tongji University opens the "Indoor Environmental Performance" in the last semester of junior year. There are 34 class hours, and the amount of class is small. In the next semester of junior year, the teaching practice is arranged, and the practical design of the interior design is carried out. The practical course tests the mastery of the students. For the student with poor mastery, the timeline is a good supplementary learning stage and it is effective consolidation for the student with great mastery. In the junior year, there is 3 weeks training about "Building Fast Design" for the student who prepares postgraduate education and working in order to strengthen their hand-drawing performance and mastery ability.

The art design major of South China Normal University opens "Design Performance Technique 1" and "Design Performance Technique 2" in the next semester of sophomore year and last semester of the junior year respectively, and course time for each course is 45 hours. In the professional limited course, the "Fast Design" is opened for a total of 60 hours. The amount of course time for the hand-drawing study is sufficient, and the hand-drawing design course is also arranged.

Tianjin Agricultural University's art design major opens three courses about performance technique. Courses last 3 semesters from the next semester of a fresh year to the last semester of junior year and span 3 academic years. In the next semester of sophomore year, the teaching practice "Sketch Skill Practice" is arranged for one week. The amount of class hours is sufficient and it can be seen that the Tianjin Agricultural University attaches great importance to the handdrawing course.

In the teaching arrangement of Nanjing Forestry University, there is no independent course for the handdrawing. The study of hand-drawing is included in the "Landscape Design" which has 64 class hours and the handdrawing study occupies the one-third of "Landscape Design". The study of hand-drawing is arranged in the next semester of a fresh year and last semester of sophomore year. After that, there is no practical teaching for the hand-drawing, but sketching study is arranged in the basic art course in the fresh year. 
TABLE II. SURVEY OF TEACHER TEACHING METHODS

\begin{tabular}{|c|c|c|c|}
\hline Teaching methods & Proportion & Ratio of demonstration and theoretical time & Ratio of Teaching and practice time \\
\hline Oral presentation of hand-drawing skills and experience & $76 \%$ & $1: 5$ & $1: 4$ \\
\hline Students compare the model & $83 \%$ & no demonstration & $1: 4-1: 7$ \\
\hline integrating oral presentation and video & $24 \%$ & $2: 5$ & $1: 2$ \\
\hline Innovative thinking and rapid expression of the teaching & $25 \%$ & & \\
\hline Arranging practical application teaching & $10 \%$ & & \\
\hline
\end{tabular}

In the teacher teaching method survey, it shows that $76 \%$ of teachers use oral presentation skills and experience. They take more time to explain theoretically and spend less on demonstrations. The ratio is 1:5. The teaching time is shorter and the practicing time is longer. The ratio is $1: 4$. $83 \%$ of the teachers ask students to compare the model, and the teachers do not demonstrate. The teaching time is shorter, and the students have a longer time to compare the model. The ratio is 1:4-1:7. Some teachers use teaching methods which is a combination of oral explanation and video. The ratio of video demonstration time and oral theory explain is 2:5. Most of teachers spend less time on teaching and more time on practicing. The ratio is $1: 2$. In the survey, $25 \%$ of teachers used innovative thinking and rapid expression, and only $10 \%$ of the practical application is arranged. As shown in TABLE II.

TABLE III. SURVEY SUMMARY IN THE PURPOSE OF LEARNING HANDDRAWING COURSE FOR STUDENTS

\begin{tabular}{|c|c|}
\hline Purpose of hand-drawing study & Proportion \\
\hline Promoting innovative thinking and helping design & $60 \%$ \\
\hline Mastering a skill & $40 \%$ \\
\hline
\end{tabular}

According to the learning purpose survey, it is found that $60 \%$ of students believe the purpose of learning hand-drawing is promoting innovative thinking and helping design, and $40 \%$ of students think that the purpose of that is only mastering a skill. The results of the survey are better than expected. Most of the students learn hand-drawing for promoting innovative thinking and helping design. As shown in TABLE III.

TABLE IV. SURVEY SUMMARY IN HAND-DRAWING COURSES ASSESSMENT AND EVALUATION METHODS

\begin{tabular}{|l|c|}
\hline \multicolumn{1}{|c|}{ Assessment and evaluation methods } & Proportion \\
\hline Submitting assignment at the end of the course & $80 \%$ \\
\hline The accumulation of usual practices & $65 \%$ \\
\hline
\end{tabular}

In the survey in hand-drawing course assessment and evaluation methods, we can clearly see that $80 \%$ of the handdrawing course assessment and evaluation methods are submitting an assignment at the end of the course, and $65 \%$ of hand-drawing courses are assessed and evaluated through the accumulation of usual practices. As shown in TABLE IV.

TABLE V. SUMMARY IN STUDENT MASTERY OF HAND-DRAWING

\begin{tabular}{|c|c|}
\hline Student mastery of hand-drawing & Proportion \\
\hline Handle design and creation skillfully anytime and anywhere & $1 \%$ \\
\hline $\begin{array}{c}\text { Cannot use the model to complete dictation and simple design } \\
\text { creation }\end{array}$ & $15 \%$ \\
\hline
\end{tabular}

\begin{tabular}{|c|c|}
\hline \multicolumn{2}{|c|}{ Cont. to TABLE V. } \\
\hline $\begin{array}{c}\text { Copying is better, can also rely on the others work to complete } \\
\text { the creation. }\end{array}$ & $65 \%$ \\
\hline \begin{tabular}{c} 
Copying is only, creation can hardly be completed \\
\hline
\end{tabular} & $20 \%$ \\
\hline
\end{tabular}

In the survey in students' hand-drawing mastery, it is found that there are only $1 \%$ of students who can design and create anytime and anywhere through the study of the course. $15 \%$ of students cannot use the model to complete dictation and simple design creation. Most students think that they are better at coping, and can rely on the work of other people to complete the creation, who account for $65 \%$ of the total number of people. $20 \%$ of students can only copy, and there is no creation can be completed. As shown in TABLE V.

TABLE VI. SUMMARY IN SCHOOL MONITORING FOR THE COURSE TEACHING

\begin{tabular}{|c|c|}
\hline School monitoring for course teaching & Proportion \\
\hline There are school leaders attending lectures and spot checks. & $65 \%$ \\
\hline There is an information collection in course quality feedback & $70 \%$ \\
\hline
\end{tabular}

The school's monitoring survey of the course teaching shows that $65 \%$ of the schools have school leaders to attend lectures, and $70 \%$ of the schools have information collection in course quality feedback, which conducts a questionnaire survey in students' mastery. As shown in TABLE VI.

\section{STATUS ANALYSIS OF THE HAND-DRAWING COURSE}

In the setting of the hand-drawing course related to the design majors of various universities in China, the handdrawing course taken as the compulsory course is the transition from the basic course to the professional course. From the table, we can see that some universities arrange sketching practices after the course and set up the fast design course in senior year or limited courses. However, some universities do not set up an independent hand-drawing course which is only included in another preliminary design course. For universities that practice sketching only in basic art courses, their emphasis is insufficient, and there are various problems in teaching, as follows:

\section{A. Single Teaching Content}

According to the investigation, many universities only pay attention to the training of hand-drawing techniques and effect picture teaching. The hand-drawing teaching content is still based on "drawing". The content of the course is a lot of drawing content such as performance and representations. There is no training in design methods, innovative thinking, and communication skills. The teaching content is single, and it is out of touch with the individual development of the 
students, market demand and the production practice. It is a common problem of hand-drawing teaching in art design majors in China, that course does not start from the characteristics of design majors[4].

\section{B. Lack of Reformation and Innovation in Teaching Methods}

In the process of teaching, the teaching method is single. The teacher pays more attention to oral and theoretical explanations rather than demonstrations. The student spends a long time on practicing but the practice is only a single copy of the model. Few teachers use special teaching methods, such as limited-time fast design training, dictation training, handdrawing competitions, going out to study and sketching, and group simulation projects. The teacher still emphasizes the refinement of the effect picture, so that students only master the basic drawing techniques in the course. There is no independent innovation ability, and therefore, in the face of actual projects, students often have no way to start drawing. The teaching model which cultivates drawing but neglects the relationship between hand-drawing and design leads to the deterioration of students' design thinking and the low level of creation.

\section{Unsound Evaluation System of Teaching Results}

It is learned from the self-made questionnaire survey that the problems in the current situation of the teaching of the hand-drawing course in China are mainly reflected in the core components of the teaching system, that is teaching objectives, teaching content, teaching methods and results evaluation. This article investigated the purpose of the hand-drawing course, the way of course assessment and evaluation, the degree of hand-drawing mastery, and the monitoring for the course teaching from universities. It can be seen that the evaluation system of hand-drawing teaching in China is incomplete and the teaching system is neglected. The teaching system ignores the training of fast design and sketches, and the requirements for the drawing effect pictures are too high. The hand-drawing course is out of line with the design, and the students' ability is insufficient using skills from hand-drawing course in design [5].

The hand-drawing effect picture course emphasizes the simulation of real scenes at the beginning of the course. One of the criteria for judging the merits of effect pictures is whether it truly reflects the design. With the development of computer technology, the restoration of the real space, materials, lighting and other environments of the computer is far superior to the hand-drawing effect. The teaching goal of the hand-drawing effect picture is out of touch with the times. And the teaching content cannot meet the needs of modern design. The teaching objectives need to be reformed so that the hand-drawing does not be replaced by computer software technology. The training goals of the hand-drawing course need to be changed to a fast design. When teaching the course, teachers should diversify their teaching methods. They should use tools which can quickly express, such as the pen and marker, rather than watercolor which is tedious expression way. The modern design emphasizes innovation. The traditional effect picture teaching is mainly based on "drawing" and the "drawing" is used instead of the "design".
The modeling ability is not equal to the design ability. The teaching goal is changed from pursuing realistic effect pictures to fast design ability, and from emphasizing the final effect performance only to focusing on the comprehensive qualities of the design concept, design process and artistic creation [6].

\section{CONCLUSION}

Hand-drawing course includes the completion of design concepts and the expression of design results, which also be known as rough drafts and design sketches, these two components are important parts of the hand-drawing course, they supplement each other, and both of them are indispensable. In the past process of teaching, the training of design sketches takes a great proportion of teaching objectives, cultivate students' ability to fast expression and communication.

\section{A. Facilitating Thought and Assisting Design}

On the basis of mastering in hand-drawing skills, promote students use eyes, brains, and hands more efficiently, which to the benefit of designers to express their design processes through a visual image way. It can help designers turn their abstract thinking into concrete thinking, also from indistinct to distinct.

\section{B. Facilitating Communication and Exchange}

Designers use hand-drawing present their designing ideas and designing schemes, also proceed effective communications with clients. Compared with literal expression, the handdrawing expression is able to transmit information by a more directly and efficiently way, especially during the definite construction plan. When there have divergences, using pens to fast drawing different thoughts on the paper is better for constructors to understand designing processes and to solve disagreements.

\section{Facilitating the Efficiency of Using Hands, Eyes and Brains Together, Improve Self-confidence.}

The different levels of Hand-drawing skills may directly affect students' interests in professional study. The student who has higher expressive abilities of bare-handed has full confidence in the professional study and also expresses their own thoughts as they want. Hand-drawing course focuses on the student who has a problem such as having grandiose aims but puny abilities, to train their operational abilities and to accelerate the development of coordination of using hands, eyes, and brains, enhancing students' confidence.

\section{REFERENCES}

[1] Xia Yanjing. Discussion on the Structure of Undergraduate Courses of Art Design in Chinese Universities [M]. Nanjing: Southeast University Press, 2011.In Chinese.

[2] Wang Dahai. The Necessity of the "Project-based Teaching" Reform Model of Environmental Art Design Specialty [A]. Liu Dali. Teaching Research in Higher Art Education [C]. Jinan: Shandong University Press, 2012.In Chinese.

[3] Xie Mingyang. Induction and Deduction in Graphics-Thinking on the Teaching of Hand-painted Performance in Environmental Art Design[J]. Decoration, 2011,10:116-118. In Chinese. 
[4] Sun Yazhen. Research on the Status Quo and Development of Environmental Art Design Education in Universities in Ningxia Region [C]. Yinchuan: Ningxia University. 2013. In Chinese.
[5] Jiang Bin. Research on Teaching Control System of Environmental Art Design Based on Cybernetics[J]. Decoration, 2011, (11): 109-111. In Chinese.

[6] Lai Haiqiang. Analysis of the curriculum of environmental art design in universities [J]. Art Education Research, 2017, 20: 123. In Chinese. 